Table 1. Cotron Rat Matings

\begin{tabular}{|c|c|c|c|c|c|}
\hline \multirow[b]{2}{*}{ Matings } & \multirow{2}{*}{$\begin{array}{c}\text { No. of } \\
\text { matings }\end{array}$} & \multicolumn{4}{|c|}{ Offspring } \\
\hline & & Type $A$ & Type $B$ & Type $C$ & Total \\
\hline \multirow[t]{2}{*}{ 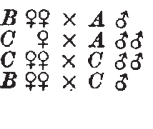 } & \multirow[t]{2}{*}{$\begin{array}{l}2 \\
2 \\
5 \\
2\end{array}$} & \multirow[t]{2}{*}{$\begin{array}{l}0 \\
1 \\
5 \\
0 \\
0\end{array}$} & \multirow[t]{2}{*}{ 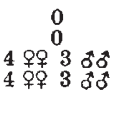 } & \multirow[t]{2}{*}{ 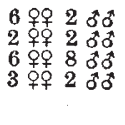 } & $\begin{array}{r}8 \\
5 \\
26 \\
12\end{array}$ \\
\hline & & & & & 51 \\
\hline
\end{tabular}

offspring in the approximate ratio $1: 2: 1$, respectively. (A chi-square analysis of the actual ratio, $5: 14: 7$, reveals that greater departures than this from the $1: 2: 1$ ratio should occur by chance about 75 per cent of the time.) Type $A$ mated to type $C$ produced only types $A$ and $C$ offspring. Type $B$ mated to type $C$ produced only types $B$ and $C$ offspring. These findings plus the observation that 21 out of 23 rats taken at random in Stanly County, North Carolina, were type $B$ (suggesting that type $B$ cotton rats breed true) indicate that types $A$ and $B$ represent the homozygotes and type $C$ the heterozygote of at least two contrasting genes. The fact that a $1: 1$ mixture of hæmoglobin from types $A$ and $B$ rats is almost indistinguishable from the hæmoglobin of type $C$ rats suggests that these hæmoglobin genes act codominantly. The genes cannot be sex-linked, for heterozygotes may be of either sex. More data are needed, however, in order to ascertain whether the hæmoglobin locus in cotton rats is simple or complex.

I am indebted to the National Science Foundation for the support of this investigation.

Biology Department, Pfeiffer College,

Misenheimer, North Carolina.

' Foreman, C. W., Amer. Midland Nat., 64, 177 (1960).

\section{A New Inheritable Property of Human Sera : the InV Factor}

Grubb and Laurell ${ }^{1}$, Harboe and Lundevall ${ }^{2}$ and Harboe ${ }^{3}$ have described the serum groups Gma, Gmx and Gmb with the help of some rheumatoid-arthritic sera which were able to agglutinate $\mathrm{O} R \mathrm{Rh}+$ red cells sensitized with an incomplete anti-D. Also with an anti-D rheumatoid-arthritic serum complex, Steinberg and Giles 4 have discovered a new factor (Gm-like) only present in the Negro sera but absent in the Whites. Ropartz et al. ${ }^{5}$ have demonstrated that some sera withdrawn from healthy donors could be used for the Gm groups typings ; in fact, such sera sometimes possess a very pure anti-Gm specificity.

In particular, we studied one of these sera, Virm (the clinical examination shows no signs of arthritic diseases and the Waaler-Rose test is positive to $1 / 64$ ). This serum, withdrawn from a blood donor, has the ability to agglutinate $\mathrm{O} R \mathrm{R}+\mathrm{red}$ cells, coated by an incomplete anti-D. We could demonstrate that : (1) some normal sera were able to inhibit its agglut. inating power ; (2) this inhibitory power is inheritable and dominant in regard to the non-inhibitory one; (3) this inhibitory property is contained in the $\gamma$-globulin fraction (Burnstein's method); (4) its relation with the Gma, Gmb and Gmx factors is actually studied.

This new serum group is temporarily called $\mathrm{InV}$. It is found in 18.52 per cent of the sera of our population chosen from Seine-Maritime, France. Of 324 in- dividuals tested, 60 were found to be $\operatorname{lnV}(+)$. The inheritance of this factor has been confirmed by the study of 34 matings yielding 74 children. Out of this family material, 25 families with both parents $\operatorname{InV}(-)$ had children who were all $\operatorname{InV}(-)$. The anti-D used for the red cells coating had the phenotype $\operatorname{InV}(+)$. We have found people $\operatorname{InV}(-)$ and InV $(+)$ whatever their phenotype regarding the Gma, Gmb and Gmx may be. Hence it seems that this new factor is independent of these other factors. But further research is necessary to disclose a possible linkage. Besides testing 399 Negroes from Dakar we have found 214 of them to be $\operatorname{InV}(+)$, that is to say, 53.63 per cent. Among these Negroes, the InV factor has been found when the individuals were Gm-like(+) as well as Gm-like $(-)$. Therefore it looks ans if the $\operatorname{InV}$ factor is also independent of the Gm-like factor described by Steinberg and Giles. This fact seems to us to be of profound importance, since until now the Negroes have appeared to possess Gm factors quite different from those of Whites. For example, all the Negroes have the phenotype: $\operatorname{Gm}(a+b+x-)^{6,7}$. Moreover, the Gm-like factor is present only among them. On the other hand, the InV factor is found in the Negro sera as well as in the White sera.

\section{Ropartz \\ J. LENOIR \\ L. RIVAT}

Centre Départemental de Transfusion Sanguine, Rouen, Seine-Maritime.

'Grubb, R., and Laurell, A. B., Acla Pathol. Microbiol. Scand., 39, 390 (1956). 2 Harboe, M., and Lundevall, J., Acta Pathot. Microbiol. Scand., 45,
357 (1959).

3 Harboo, M., Acta Pathol. Microbiol. Scand., 47, 191 (1959).

4 Steinberg, A. G., Giles, B. D., and Stauffer, R., Amer. J. Human Genet., 12, 44 '(1960).

${ }^{5}$ Ropartz, C., Lenoir, J., Hemet, Y., and Rivat, L., Nature, 188, 1120 (1960).

- Ropartz, C., Rivat, L., and Lenoir, J., Rev. Frans. Etudes Clin. et Biol, 5,814 (1960)

' Steinberg, A. G., Boyer, S., and Stauffer, R., Nature, 188, 169 (1960).

\section{Delayed Hypersensitivity to Homologous $\gamma$-Globulin in the Guinea Pig}

THE existence in the rabbit of genetically determined antigenic differences ('allotypes') among homologous $\gamma$-globulins has been described by Oudin, who succe日ded in preparing precipitating antisera against them after prolonged immunization with specific immune precipitates in adjuvants ${ }^{1}$. Considerable work has been done in an attempt to define the number of distinct serological groups and the number of genes controlling them in the rabbit'. The allotypic groups have been reported to be located on fragments I and II (as defined by R. R. Porter) of $\gamma$-globulin digested with papain ${ }^{3}$.

Previous work on allotypes has been confined to the rabbit and to precipitating antibodies, with the exception of a statement by Oudin that he was able to observe some weak intraspecific precipitin reactions in guinea pigs ${ }^{4}$. In the present investigation, it is shown that guinea pigs, immunized with homologous $\gamma$-globulin in adjuvants, will rapidly develop a state of delayed hypersensitivity to the immunizing antigen, in the absence of antibody detectable by systemic anaphylaxis.

The experiments were carried out on white guinea pigs weighing $300-450 \mathrm{gm}$. In each experiment, 